JURNAL PIWULANG, Vol. 2 No. 1 September 2019, 35-48

\title{
EFEKTIVITAS METODE AL-MIFTAH LIL 'ULUM DALAM MENINGKATKAN KUALITAS MEMBACA KITAB KUNING PADA SANTRI MADRASAH DINIAH
}

\author{
Oleh: \\ Ibnu Ubaidillah' ${ }^{1} \&$ Ali Rif'an ${ }^{2}$ \\ Email: masmizoneindesign@gmail.com \\ Email: pesma83@gmail.com
}

\begin{abstract}
This study uses a qualitative descriptive method with a case study approach. Data collection techniques use the method of interview, observation, and documenta-tion. Data analysis is done by condensing data, then presenting data, and conclusions drawn from the data. In checking the validity of the data, researchers use methods, namely extending the time of partici-pation of researchers in the field, increasing persistence of observation, using appropriate reference materials, and reading book tests. The results of the analysis show that the process of applying the Al-Miftah Lil 'Ulum Method at Madin Wustho Hidayatul Mubtadi'in -Malang City was carried out through several stages, namely preparation, implementation, and evaluation. Among the supporting factors of the learning process and the inhibiting factors to applied it.
\end{abstract}

\section{Abstrak}

Penelitianini menggunakan deskriptif kualitatif dengan jenis studi kasus. Pengumpulan data menggunakan metode wawancara, observasi, dan dokumentasi. Analisis data dilakukan dengan pengkondensasian data, kemudian penyajian data, dan dari data yang telah disusun tersebut ditarik kesimpulan. Dalam pengecekan keabsahan data, peneliti menggunakan cara, yaitu memperpanjang waktu keikutsertaan peneliti di lapangan, meningkatkan ketekunan pengamatan, menggunakan bahan referensi yang tepat, dan tes baca kitab. Proses penerapan Metode Al-Miftah Lil 'Ulum di Madin Wustho Hidayatul Mubtadi'in - Kota Malang dilaksanakan melalui 3 tahapan, yaitu persiapan, pelaksanaan, dan evaluasi. Disamping tahapan yang dilaksanakan, ada beberapa pendukung dalam proses pembelajarannya serta tantangan (hambatan) dalam mewujudkannya.

Kata kunci: Metode Al-Miftah Lil ‘Ulum, Kitab Kuning, Santri Madin

\footnotetext{
${ }^{1}$ Guru Madin dan Guru Al Qur'an di SMA 2 Batu - Indonesia

${ }^{2}$ Dosen STAI Ma'had Aly Al Hikam Malang - Indonesia
} 


\section{A. Pendahuluan}

Pondok Pesantren merupakan basis lembaga pendidikan Islam paling kuno di Indonesia. Dinamika masa dan perkembangan budaya masyarakat yang semakin modern ini, tentunya merubah beberapa hal yang ada di pesantren. Oleh sebab itu, pesantren pun berkembang menjadi 2 (dua) tipe: salafi dan kholafi. Pesantren salafi tetap melestarikan kitab-kitab klasik sebagai mata pelajarannya, sedangkan pesantren kholafi mendistribusikan beberapa materi pelajaran umum. Perubahan juga terjadi pada sistem pendidikannya. Pembelajaran di pesantren sekarang menggunakan sistem madrasah dengan berbagai macam tipologinya. ${ }^{3}$

Pesantren menekankan isi/materi pembelajarannya pada hasil karya ulama-ulama salaf (terdahulu) yang pada akhirnya dikenal dengan istilah kutub al-shafrâ' (kitab kuning). Kitab kuning yang dipelajari dan diajarkan kepada santri di pondok pesantren, umumnya berhaluan ahli sunah waljamaah, baik dari segi akidah, fikih, maupun tasawufnya. Di antara peranti penting dalam mempelajari dan menguasai isi dari kitab kuning secara komprehensif adalah penguasaan ilmu alat. Ilmu alat yang dimaksud adalah nahu, saraf, lughah, dan balaghah. Ilmu tersebut menjadi studi paling diprioritaskan di pesantren sebagai upaya untuk menjadikan santri sebagai kader-kader yang memiliki pemahaman benar dan baik terhadap Alquran dan Sunah melalui penjelasan ulama dalam kitab kuningnya.

Materi nahu saraf di pesantren, biasanya menggunakan beberapa kitab pokok klasik, seperti Jurumiyah, 'Imrithi, dan Alfiyah. Namun, dengan kemajuan masa, para pengembang kurikulum pesantren berinisiatif untuk merancang sebuah metode praktis belajar nahu saraf. Salah satu metode tersebut bernama Al-Miftah Lil 'Ulum yang dirancang dan didesain oleh Badan Tarbiyah Wa Ta'lim Madrasi (Batartama) Pondok Pesantren Sidogiri untuk santri baru tingkat i'dadiyah (pemula).

Metode Al-Miftah Lil 'Ulum sendiri merupakan rangkuman padat dari kitab Jurumiyah, Imrithi, dan Alfiyah. Oleh sebab itu, dalam metode ini tidak dimunculkan istilah-istilah baru dalam ilmu nahu, bahkan tetap mempertahankan keoriginalitasan istilah dari kitab nahu klasik. Selain itu, materi yang dikutip merupakan kaidah-kaidah nahu dan saraf yang digunakan untuk keterampilan membaca kitab saja tanpa adanya pendalaman materi yang meluas dan panjang lebar. ${ }^{4}$

\footnotetext{
${ }^{3}$ Abdulloh Hamid, Pendidikan Karakter Berbasis Pesantren: Pelajar dan Santri dalam Era IT \& Cyber Culture, (Surabaya: Imtiyaz, 2017), hlm. 49.

${ }^{4}$ Rifqi Al-Mahmudy, Training Metode Baca Kitab Al-Miftah Lil 'Ulum Sidogiri: Pengenalan Dasar Metode Al-Miftah Lil 'Ulum (Pasuruan, 21 Juli 2018).
} 
Konten dari Metode Al-Miftah Lil 'Ulum memiliki karakteristik yang unik. Materi ditampilkan dengan bahasa Indonesia yang lugas, jelas, singkat, dan mudah dipahami. Selain itu, juga dilengkapi dengan rumus, ciri-ciri, tabel contoh, dan skema materi yang disajikan dengan warnawarna bervariasi. Di sisi lain, materi-materi nahu sarafnya dikolaborasikan dengan lagu anak dan lagu daerah yang sudah sangat familier.

Asas paling urgen dalam efektivitas pembelajaran sendiri adalah dengan waktu yang sama, menghasilkan kualitas yang berbeda; kualitas sama dengan durasi lebih singkat; kualitas lebih baik dengan kurun waktu singkat. Namun, efektivitas pembelajaran dari sebuah metode yang diterapkan dalam sebuah lembaga akan menunjukkan perbedaan signifikan dengan lembaga lain yang juga sama-sama menerapkan metode tersebut. Hal ini, tentunya dipengaruhi oleh beberapa hal, baik dari segi proses, faktor pendukung dan penghambatnya.

Madrasah Diniah Hidayatul Mubtadi'in telah menerapkan metode ini pada awal tahun 2016. Dalam kurun waktu tersebut, setidaknya sudah bisa dianalisis efektivitas yang dicapai selama proses dan hasil pembelajarannya. Maka dari itu, tujuan penelitian penerapan Metode AlMiftah Lil 'Ulum di Madin Wustho Hidayatul Mubtadi'in adalah berusaha mendeskripsikan penerapan, efektivitas pembelajaran, serta faktor-faktor pendukung dan penghambat selama proses pembelajaran.

\section{B. Kajian Teori}

\section{Efektivitas Pembelajaran}

Dalam dunia pendidikan, efektivitas pembelajaran menyangkut dua sudut pandang yang sangat penting, yaitu efektivitas pengajar dan objek pengajaran (siswa/santri). Perencanaan yang baik terhadap berbagai jenis kegiatan belajar-mengajar akan mempengaruhi efektivitas pengajaran seorang guru. Sementara itu, tujuan pembelajaran yang dirumuskan dengan jelas akan memberikan dampak yang signifikan pada hasil pembelajaran yang telah ditempuh. ${ }^{5}$ Ada tiga dimensi yang memiliki pengaruh besar terhadap efektivitas pembelajaran, yaitu dimensi situasi, subtansi, dan penyampaian. Situasi pembelajaran yang efektif tidak hanya terfokus pada kegiatan yang bersifat informing dan instructing, tetapi juga mampu menciptakan suasana pembelajaran yang bersifat entertaining (memberi hiburan) sehingga siswa mampu mengeksplorasi manfaat dari setiap materi yang disampaikan. Kemampuan siswa dalam mengkontekstualisasikan setiap materi ajar merupakan efektivitas yang perlu dicapai dalam sudut pandang subtansi. Dari sini, seorang guru tidak hanya

\footnotetext{
${ }^{5}$ Eko Susilo Madya, Dasar-Dasar Pendidikan, (Semarang: Effhar Effset, 2011), hlm. 63.
} 
berorientasi pada usaha pemahaman materi secara tekstual saja. Keterlibatan siswa dalam proses belajar-mengajar secara maksimal akan menentukan hasil pembelajaran. Oleh sebab itu, fokus guru tidak hanya pada telling dan showing saja, tetapi berkembang pada kegiatan yang melibatkan peserta secara komprehensif. ${ }^{6}$

Efektivitas pembelajaran juga bergantung pada beberapa faktor yang sangat berpengaruh, di antaranya faktor internal (mencakup kondisi psikis, fisik, dan SDM dalam diri guru dan siswa), faktor eksternal (lingkungan belajar), desain pembelajaran (strategi, metode, teknik, dan materi belajar), dan administrasi lembaga yang bersangkutan.

Tolok ukur efektivitas pembelajaran diklasifikasikan dalam 4 (empat) tingkatan, yaitu 1) cumlaude, jika 100\% materi telah dikuasai; 2) optimal, jika 76-99\% dituntaskan siswa; 3) minimal, 60-75\% telah tuntas; 4) less, hanya $60 \%$ yang dikuasai. ${ }^{7}$ Beberapa kriteria yang menjadi indikator efektivitas pembelajaran, di antaranya 1) perangkat pembelajaran yang telah dipersiapkan dengan baik dan komplet; 2) standar kompetensi (SK) dan kompetensi dasar (KD) dirumuskan secara detail; 3) karakter guru berwibawa dengan gaya dan suara yang jelas dan keras; 4) materi ajar sinkron dengan tujuan pembelajaran; 5) guru menguasai materi, situasi, media, dan andal dalam mengimplementasikan desain pembelajaran. ${ }^{8}$

Dalam pembelajaran kitab kuning melalui metode baca kitab, setidaknya ada 3 (tiga) indikator yang menunjukkan pembelajaran tersebut bisa dianggap efektif. Pertama, kemampuan menejerial dan penguasaan secara total terhadap materi ajar bagi guru sehingga nuansa belajar yang menye-nangkan dan penuh inovasi terwujud dengan intensif. Kedua, adanya sinkronisasi antara teoretis dan praktis dalam membaca kitab kuning bagi siswa dengan standar kaidah nahu saraf. Ketiga, kompetensi siswa dalam membaca kitab kuning dengan baik dan lancar ditempuh dalam kurun waktu \pm 2 tahun.

\section{Metode Pembelajaran Kitab Kuning: Al Miftah lil Ulum}

Pada umumnya, pembelajaran kitab kuning masih menggunakan beberapa metode pembelajaran tradisional yang klasik dan salaf. Di antara metode itu adalah a) metode bandongan, yaitu santri memaknai kitab gundul/bermakna yang dibacakan dan dijelaskan oleh kiai/ustaz sembari mencatat keterangan-keterangan yang diperoleh selama kegiatan mengaji berlangsung; b) metode

\footnotetext{
${ }^{6}$ M. Gorky Sembiring, Menjadi Guru Sejati, (Yogyakarta: Galang Press, 2009), hlm. 97-98.

${ }^{7}$ Syaifu Bahri Djamarah, Strategi Belajar Mengajar, (Jakarta: PT Rineka Cipta, 2013), hlm. 121.

${ }^{8}$ Tim Penyusun Didaktik Kurikulum IKIP Surabaya, Pengantar Didaktik Metodik Kurikulum PBM, (Surabaya: Rajawali Pers, 2011), hlm. 164-166.
} 
sorogan, yaitu santri membacakan kitab yang telah dipelajari atau dicari maknanya di hadapan guru/kiai. Sementara itu, guru menyimak dan memberi pertanyaan mengurai dari bacaan santri dan mengoreksi bila ada bacaan yang salah; c) metode hafalan, digunakan untuk menguasai materi-materi kitab kuning, baik yang berupa nazam (materi dengan format syair) atau natsar (materi yang disajikan dalam gaya prosa); d) metode bahtsu al-masāil, diterapkan dalam pembelajaran yang menggunakan metode diskusi, metode ini merangsang santri untuk berpikir kritis sitematis dalam menyelesaikan pokok permasalahan yang dibahas. Selain itu, metode ini merupakan media untuk mengasah kompetensi analisis, berargumentasi, dan adu pendapat.

Metode ini dirintis oleh Ahmad Qusyairi Isma'il dan dikembangkan Batartama (Badan Tarbiyah wa Ta'lim Madrasi) setelah mendapat mandat dari pihak Pengasuh Pesantren Sidogiri. Metode ini diimplementasikan pada kelas persiapan sebagai peranti dasar untuk memahami kitab Fath al-Qarīb. "Mari berpartisipasi menghidupkan kembali gairah baca kitab kuning di Nusantara" merupakan slogan metode Al-Miftah dalam memotivasi setiap lembaga, baik pesantren atau madrasah untuk meningkatkan semangat mempelajari kitab kuning. Selain itu, moto metode Al-Miftah adalah "Mudah belajar membaca kitab."

Strategi pembelajaran dalam metode Al-Miftah menggunakan modul learning. Jadi, siswa yang sudah mencapai target akan langsung naik tingkat tanpa menunggu peserta didik seangkatannya (akselerasi). Pembagian kelas dibagi menjadi 2 (dua): kelas jilid dan praktikum (sorogan Fath al-Qarīb). Target kelas jilid adalah menguasai dan hafal teori nahu saraf jilid 1-4 dan target kelas praktikum, siswa telah mampu menerapkan teori jilid 1-4 dan bantuan kamus dalam membaca teks kitab Fath al-Qarīb dengan baik, benar, dan lancar. Dalam jurnal metode Al-Miftah, kelas jilid secara normal ditempuh selama 113 TM (tatap muka) dalam durasi 1 jam pelajaran, untuk jurnal 2 jam setiap TM membutuhkan 59 TM (penyelesaian jilid 1-4).

Al-Miftah terdiri dari 7 (tujuh) buku: 4 buku berisi teori nahu saraf jilid 1-4, 1 buku tashrif Al-Miftah, 1 buku berisi nazam Al-Miftah bahasa Indonesia dan Arab, 1 buku panduan bertanya (pegangan guru). Secara detail, isi buku Al-Miftah jilid 1-4 dijelaskan pada gambar di bawah ini. 
JURNAL PIWULANG, Vol. 2 No. 1 September 2019, 35-48

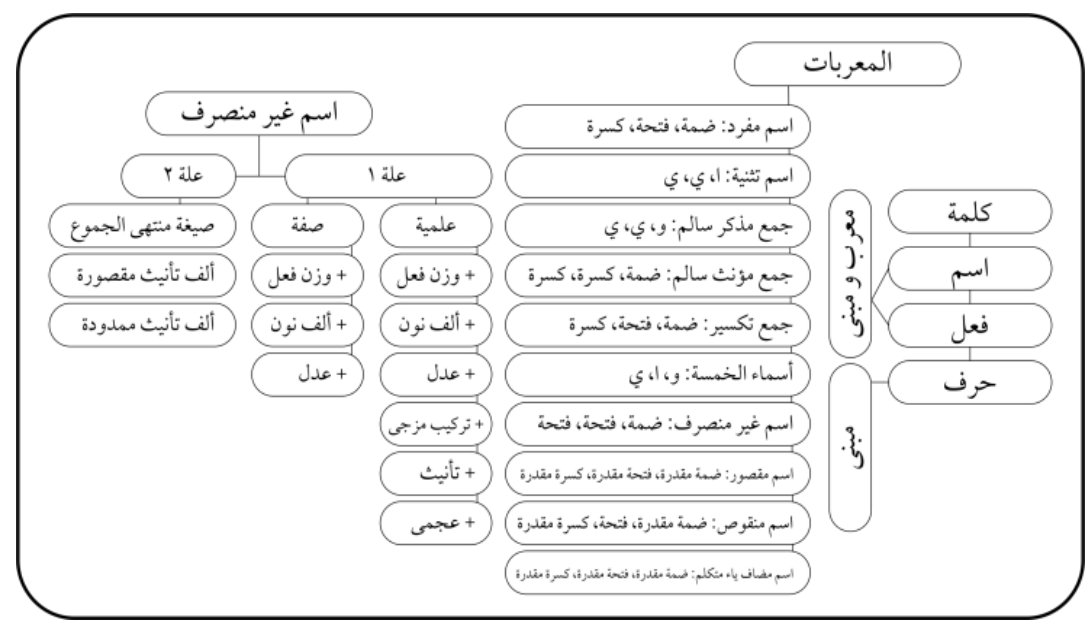

Gambar 1: Skema Jilid 1

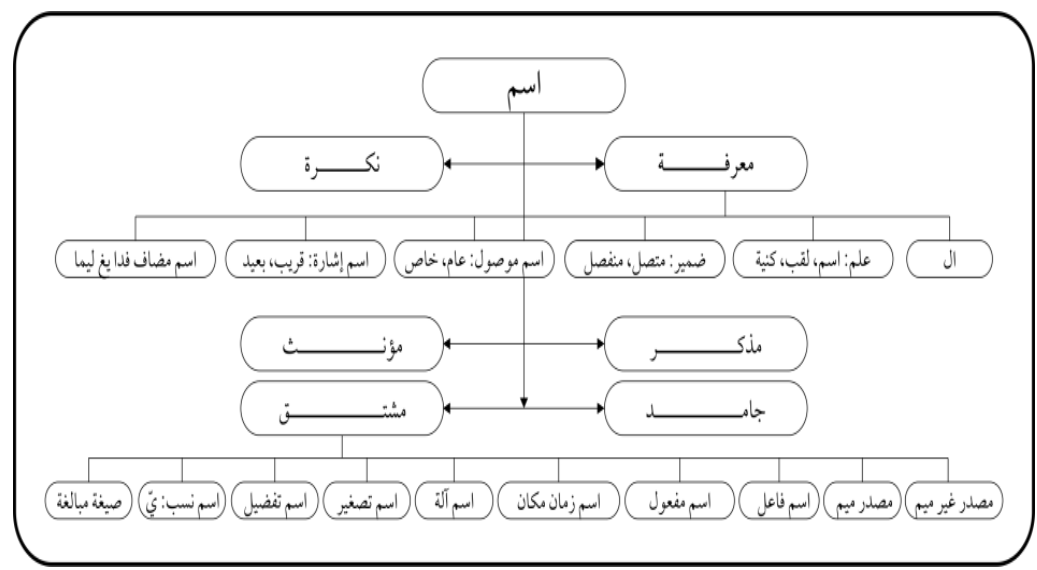

Gambar 2: Skema Jilid 2

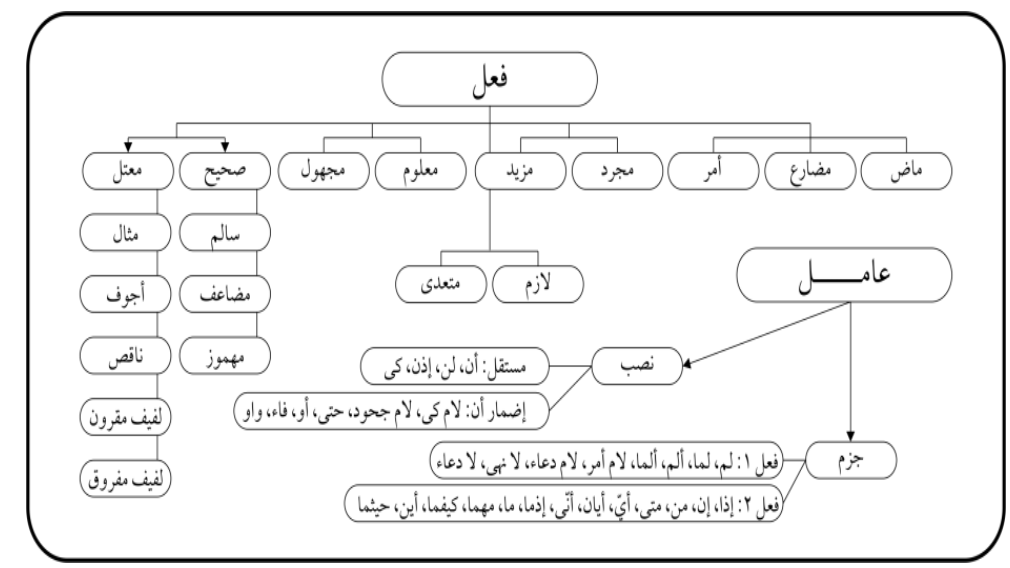

Gambar 3: Skema Jilid 3 


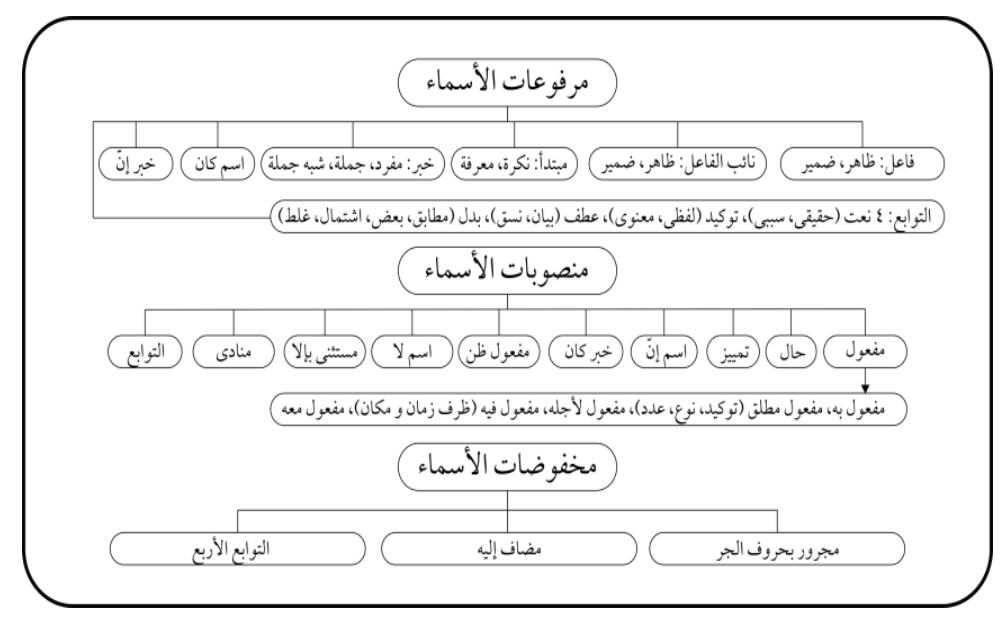

Gambar 4: Skema Jilid 4

Di antara metode yang digunakan dalam pembelajarannya adalah a) metode memahami dan menghafal, diterapkan agar siswa menguasai secara menyeluruh teori jili $1-4$; b) metode 5 jari, diterapkan pada materi isim damīr untuk mengurai gender dan pelaku kata kerja; c) metode takrār, diterapkan pada saat tanya jawab materi sesuai buku Panduan Bertanya.

Untuk evaluasi, digunakan tes tulis dan baca. Kelas jilid memakai tes tulis dengan format soal yang disusun tim Al-Miftah dan tes baca telah ditetapkan materinya pada buku Panduan Bertanya. Sedangkan kelas praktikum hanya menerapkan tes baca dengan aturan yang harus diperhatikan, yaitu kesalahan yang dilakukan tidak lebih dari dua dalam kaidah yang berbeda dan tidak boleh melakukan kesalahan lebih dari satu pada kaidah yang sama.

\section{Kemampuan Membaca Kitab Kuning}

Tolok ukur kemampuan membaca kitab kuning dipandang dalam dua aspek penting: aspek nahu dan aspek saraf. Dalam aspek nahwu, ada 3 kriteria, yaitu 1) peserta didik mampu menyebutkan dan membedakan kelas kata dari teks kitab yang dibaca beserta tandatandanya; 2) peserta didik mampu menguraikan secara detail status kata, baik itu dari segi mabni/mu'rabnya, tanda i'rab, dan alasan i'rab; 3) peserta didik mampu menentukan kedudukan kata beserta i'rab-nya dalam kalimat. Dari aspek saraf, hendaknya siswa mampu untuk 1) menentukan wazan (bentuk kata dari segi pelafalan) dan sigat (bentuk kata dari segi makna) dari kata yang dibaca dalam kalimat. Kemampuan menentukan wazan dan sigat ini adalah keterampilan yang sangat urgen dalam ilmu saraf; 2) mengurai dan men-tasrif (baik istilahi atau lugawi) kata dalam teks yang dibaca; 3) menyelaraskan 
(muthobaqoh) kalimat yang ada pada teks dengan contoh kata yang ada di dalam kitab Tasrif.

\section{Metode Penelitian}

Penelitian ini menggunakan metode deskriptif kualitatif dengan jenis studi kasus. Lokasi penelitian dilakukan di Madin Wustho Hidayatul Mubtadi'in Kota Malang pada kelas jilid dan praktikum. Adapun instrumen penelitiannya menggunakan tiga hal, yaitu 1) informan (orang-orang yang menjadi sumber data); 2) media perekam, meliputi dokumen foto, audio, dan visual; 3) alat tulis, untuk keperluan wawancara dan observasi. Subjek penelitian difokuskan pada tiga informan, yaitu kepala madin, guru khusus pengajar metode Al-Miftah, dan santri tingkat wustho. Teknik penelitian ini memakai sampling, yaitu meneliti sebagian yang dapat mewakili secara keseluruhan dari populasi terpilih. Bentuk yang digunakan adalah snowball sampling sehingga konteks dari sumber informasi benar-benar diketahui secara detail dan komprehensif. ${ }^{9}$

Teknik pengumpulan data memakai tiga cara, yaitu wawancara (interview), observasi, dan dokumentasi. Wawancara yang digunakan adalah jenis wawancara bebas tanpa menggunakan pedoman dan format yang dibakukan. Observasi yang dilaksanakan menggunakan observasi langsung dan sistematis dengan menentukan objek yang diobservasi secara jelas dan tepat. Dokumentasi meliputi data berupa file yang dimiliki pihak madrasah, pemotoan lokasi, dan proses pembelajaran. Teknik analisis data dalam penelitian ini menggunakan analisis model alir terbaru Miles, Huberman, dan Saldana. ${ }^{10}$ Tahapannya adalah kondensasi data, penyajian data, dan verifikasi (penarikan kesimpulan). Adapun pengecekan keabsahan data menggunakan beberapa cara, di antaranya 1) menambah durasi observasi peneliti di lapangan; 2) pengamatan secara teliti terhadap data yang diperoleh; 3 ) mengadopsi referensi yang tepat; 4) tes baca kitab kuning bagi kelas praktikum.

\section{Hasil Penelitian}

Proses kegiatan belajar-mengajar metode Al-Miftah Lil 'Ulum yang telah diterapkan di madin Wustho Hidayatul Mubtadi'in dilaksanakan melalui beberapa fase (tahapan), tahapan tersebut dimulai dari tahap persiapan yang meliputi a) menetapkan tujuan pembelajaran yang isinya adalah agar para santri mampu membaca kitab kuning dengan benar sehingga mampu memahami Alquran dan Sunah sesuai dengan

\footnotetext{
${ }^{9}$ A. Muri Yusuf, Metode Penelitian Kuantitatif, Kualitatif \& Penelitian Gabungan, (Jakarta: Kencana, 2017), hlm. 328.

10 Mattew B. Mile, A. Michhail Huberman \& Jhoni Saldana. Qualitatif Data Analysis: A Methode Surcebook: third edition (USA: Arizona State Univercity, 2014). HIm. 84
} 
haluan ahlisunah waljama'ah; b) bahan ajar, sebagaimana telah ditetapkan dalam jurnal Al-Miftah; c) target pencapaian, disesuaikan dengan kurun waktu menyelesaikan jenjang wustho selama 3 tahun; d). menyusun alat evaluasi, evaluasi telah dirancang dengan seksama sesuai dengan buku Panduan Bertanya Al-Miftah.

Tahap selanjutnya, pelaksanaan pembelajaran mencakup beberapa informasi yang diringkas pada poin-poin berikut ini.

Pertama, waktu pembelajaran dimulai hari Sabtu sampai dengan hari Rabu pukul 09.00-10.00 WIB dengan durasi waktu 60 menit per TM (tatap muka).

Kedua, pembagian kelas metode Al-Miftah di Madin Hidayatul Mubtadi'in terdiri dari 4 kelas, 3 kelas untuk jilid dan 1 kelas praktikum. Pada tingkat jilid, ada satu kelas yang memegang 2 jilid sekaligus, mengingat jumlah guru yang tersertifikasi metode Al-Miftah hanya 4 orang.

Ketiga, proses pembelajaran metode Al-Miftah dilaksanakan melalui tahapan-tahapan berikut.

a) Pembukaan dan doa (5 menit);

b) Membaca nadham Al-Miftah berbahasa Arab bersama-sama (5 menit);

c) Guru menyampaikan apersepsi (5 menit);

d) Guru menyampaikan materi baru/penanaman konsep (15 menit);

e) Guru memahamkan dan menguatkan hafalan terhadap teori yang telah dipelajari dengan mengajukan pertanyaan kepada masingmasing santri (15 menit);

f) Evalusi dan doa, santri mengerjakan soal yang ada di buku jilid AlMiftah (15 menit).

Dalam kelas praktikum, masih menggunakan metode klasik pesantren yaitu sorogan, santri menyetorkan bacaan kitab Fath al-Qarīb sesuai materi yang telah ditentukan guru. Sebelum menyetorkan bacaan, santri diberikan tugas untuk mencari makna dari setiap kata, baik lewat kamus atau kitab yang sudah ada maknanya (pethuk-an), kemudian santri menentukan sendiri tarkib dari teks yang dibaca dengan teori yang sudah dipelajari di jilid 1-4. Guru menyimak bacaan santri sekaligus membetulkannya jika terjadi kesalahan dan memberi beberapa pertanyaan seputar nahu saraf.

Keempat, metode pembelajaran Al-Miftah Lil 'Ulum yang sudah diterapkan di Madin Wustho Hidayatul Mubtadi'in adalah sebagai berikut.

a. Metode Ceramah, digunakan ketika guru menyampaikan materi baru dalam jilid dengan memberikan beberapa contoh mudah kalimat di papan tulis. Metode ini diterapkan untuk memberikan 
pemahaman dasar kepada santri tentang teori-teori yang dipelajari.

b. Metode Tanya Jawab, digunakan ketika menyampaikan apersepsi. Guru menanyakan sejumlah pertanyaan yang berkaitan dengan materi-materi yang telah dipelajari sebelumnya. Dengan metode ini, santri akan lebih mudah untuk memahami dan menghubungkan teori yang sudah dipelajari dengan teori baru yang akan disampaikan guru.

c. Metode Takror, yaitu mengulang beberapa pertanyaan sesuai urutan yang ada di buku Panduan Bertanya Al-Miftah pada setiap santri untuk menguatkan hafalan teori yang telah dipelajari.

d. Metode Menghafal, materi yang dihafalkan adalah teori-teori yang ada di buku jilid dan buku nadham Al-Miftah. Di Madin Wustho Hidayatul Mubtadi'in, hanya nadham berbahasa Arab yang dihafalkan, untuk yang berbahasa Indonesia tidak dihafalkan, mengingat santri sudah banyak yang hafal nadham 'Imrithi.

Pada tahap evaluasi, digunakan tes tulis dan lisan. Tes kenaikan jilid memakai tes tulis dan lisan dengan ketentuan nilai 80. Jika tidak mencapai nilai yang ditargetkan tersebut, maka santri mengulang lagi di kelas tersebut. Tes lisan dinilai langsung oleh guru senior yang mengajar di Madin 'Ulya. Tes kenaikan jilid ini sendiri diadakan di tiap akhir semester. Khusus untuk kelas praktikum hanya dilaksanakan tes baca saja. Soal-soal tes tulis memakai bentuk soal yang telah disusun oleh Metode Al-Miftah.

Mengenai efektivitas pembelajarannya, terdapat 3 poin penting, di antaranya 1) efektivitas pengajar, selama proses pembelajaran, guru mampu menguasai situasi dan kondisi kelas, sehingga suasananya tenang dan terkendali. Interaksi antara guru dan santri terjalin dengan baik, terutama saat guru menerapkan metode tanya jawab setelah penanaman konsep di awal; 2) peserta didik, kondisi siswa pada saat pembelajaran berjalan dengan baik, kondisi tenang, dan terkontrol mengikuti tahapantahapan yang dilaksanakan guru. Interaksi antara guru dan siswa begitu nampak jelas, sehingga suasana kelas lebih hidup; 3) kualitas hasil pembelajaran, dari hasil tes tulis, diketahui bahwa terdapat peningkatan yang signifikan pada sebagian besar santri. Nilai yang diperoleh dari hasil ujian, banyak yang melebihi target nilai yang ditentukan, Untuk tes lisan yang telah dilaksanakan, ada beberapa indikator yang menunjukkan kemajuan yang signifikan pada kemampuan membaca kitab santri. Diantaranya, urutan pertanyaan seputar nahu dijawab oleh santri dengan jawaban yang tepat, mampu men-tasrif beberapa kata kerja yang diajukan penguji. Untuk muthobaqoh/ menyelaraskan kata kerja, santri masih 
mengalami kesulitan meskipun hal ini bukan menjadi target pembelajaran Al-Miftah.

Adapun faktor-faktor yang mendukung penerapan pembelajaran Metode Al-Miftah Lil 'Ulum di Madin Wustho Hidayatul Mubtadi'in adalah: Sumber Daya Manusia (SDM) yang profesional, materi yang simpel dan mudah, sarana dan prasarana yang memadai, Ketekunan belajar santri. Faktor-faktor penghambat dalam pembelajaran Metode Al-Miftah tidak secara totalitas mempengaruhi perkembangan belajar santri. Faktor penghambat ini juga tidak selalu terjadi pada setiap santri dan hanya terjadi pada waktu tertentu. Sesuai hasil temuan, faktor penghambat yang terjadi adalah: kedisiplinan guru dan peserta didik, alokasi waktu yang minim, lingkungan belajar yang kurang mendukung.

Beberapa hal yang dijelaskan dalam teori mungkin tidak sama persis dengan yang terjadi dalam kenyataan atau bahkan sebaliknya. Oleh sebab itu, perlu pengkajian yang lebih mendalam pada fenomenafenomena yang ditemukan. Data yang ditemukan akan dianalisis peneliti melalui beberapa rumusan pembahasan.

Dalam modul yang disusun setidaknya membutuhkan 113 kali tatap muka untuk menyelesaikan 4 jilid dengan durasi 60 menit tiap pertemuan. Sedangkan yang diterapkan di Madin Hidayatul Mubtadi'in adalah pembelajaran tiap jilid diselesaikan pada satu semester dengan melakukan penguatan dan pengulangan pada materi yang telah diselesaikan. Untuk kenaikan jilidnya sendiri dilakukan tes yang dilaksanakan tiap semester bersamaan dengan ujian madrasah. Pembagian kelas Metode Al-Miftah di Madin Wustho Hidayatul Mubtadi'in sudah sesuai dengan pembagian tingkatan kelas yang sudah dipaparkan. Perbedaannya, ada satu guru yang memegang 2 jilid sekaligus yang seharusnya 4 jilid Al-Miftah dipegang oleh 4 guru yang berbeda. Pada tahapan pembelajaran semua materi Metode Al-Miftah telah dipakai Madin Hidayatul Mubtdi'in kecuali target hafalan nadham Al-Miftah yang berbahasa Indonesia. Saat pelaksanaan hanya nadham berbahasa Arab yang dihafalkan mengingat isi dari keduanya sama saja dan agar lebih efektif terhadap pengalokasian waktu yang sangat minim.

Penerapan pada kelas praktikum sesuai dengan yang ditetapkan pada metode Al-Miftah yakni memakai metode sorogan. Namun sarana pembelajaran berupa kamus kata Fath al-Qarīb yang disusun Batartama belum terpenuhi, santri hanya memakai kamus bahasa Arab biasa untuk mencari makna kata sebelum menyetorkan bacaannya kepada guru penyimak.

Menurut Djamarah, hasil pembelajaran yang telah dicapai peserta didik bisa digunakan dan menjadi tolok ukur untuk melihat efektivitas pembelajaran yang telah dilaksanakan. Hasil pembelajaran dikatakan 
efektif jika batas minimal $75 \%$ dari tujuan dan hasilnya telah dipenuhi. ${ }^{11}$ Dari hasil wawancara peneliti terhadap Kepala Madin, beliau menjelaskan bahwa peningkatan nilai peserta didik cukup bagus, secara keseluruhan 80\% dari 25 siswa Madin Wustho Hidayatul Mubtadi'in mendapat nilai yang melebihi dari target yang ditentukan yaitu 80, baik ujian tulis maupun tes baca. Indikator lain seperti kuantitas unjuk kerja sebagai penunjuk efektivitas pembelajaran bisa dilihat dari hasil nilai tes baca, siswa mampu menjawab pertanyaan serta menguraikan teori dari materi tes yang diujikan dengan baik dan lancar.

\section{E. Kesimpulan dan Saran}

Berdasarkan hasil penelitian yang telah diuraikan dalam pembahasan yang berkaitan dengan "Efektivitas Penerapan Metode AlMiftah Lil 'Ulum dalam Meningkatkan Kualitas Membaca Kitab Kuning pada Santri dapat disimpulkan beberapa hal, di antaranya:

1) Proses penerapan Metode Al-Miftah Lil 'Ulum di Madrasah Diniah Hidayatul Mubtadi'in dilaksanakan melalui beberapa tahapan, yaitu: persiapan, pelaksanaan, dan evaluasi. Persiapan meliputi tujuan pembelajaran, materi/bahan ajar, target pencapaian, dan menyusun alat evaluasi. Tahap pelaksanaan menyangkut waktu pembelajaran, pembagian kelas dan proses pembelajaran. Pada tahap evaluasi menggunakan tes tulis dan lisan; penerapan Metode ini telah berjalan cukup baik dan efektif. Hal ini bisa diketahui lewat usaha yang maksimal dari pihak Pengurus dan segenap jajaran ustaz. Adapun efektivitas Metode Al-Miftah ini bisa dilihat dari beberapa indikator, antara lain: nilai ujian santri melebihi target yang ditentukan, menguasai dan menghafal seluruh materi yang diajarkan pada jilid 1-4, santri mampu menerapkan teori nahu saraf yang dipelajari dalam membaca kitab kuning dengan tepat;

2) Di antara faktor-faktor yang mendukung penerapan pembelajaran Metode Al-Miftah Lil 'Ulum di Madin Wustho Hidayatul Mubtadi'in adalah: Sumber Daya Manusia (SDM) yang profesional, materi yang simpel dan mudah, sarana dan prasarana yang memadai, Ketekunan belajar santri. Faktor-faktor penghambat dalam pembelajaran Metode Al-Miftah tidak secara totalitas mempengaruhi perkembangan belajar santri. Faktor penghambat ini juga tidak selalu terjadi pada setiap santri dan hanya terjadi pada waktu tertentu. Sesuai hasil temuan, faktor penghambat yang terjadi adalah: kedisiplinan guru dan peserta didik, alokasi waktu yang minim, lingkungan belajar yang kurang mendukung.

11Syaifu Bahri Djamarah, Strategi Belajar Mengajar, (Jakarta: PT. Rineka Cipta, 2013), hlm. 121. 
JURNAL PIWULANG, Vol. 2 No. 1 September 2019, 35-48

\section{Daftar Rujukan}

Al-Mahmudy,. Rifqi 2018. Training Metode Baca Kitab Al-Miftah Lil 'Ulum Sidogiri: Pengenalan Dasar Metode Al-Miftah Lil 'Ulum. Pasuruan 21 Juli

Djamarah, Syaifu Bahri. 2013. Strategi Belajar Mengajar. Jakarta: PT Rineka Cipta.

Hamid, Abdulloh. 2017. Pendidikan Karakter Berbasis Pesantren: Pelajar dan Santri dalam Era IT \& Cyber Culture. Surabaya: Imtiyaz.

Madya, Eko Susilo. 2011. Dasar-dasar Pendidikan. Semarang: Effhar Effset.

Mile, Mattew B. A. Michhail Huberman \& Jhoni Saldana. 2014 ualitatif Data Analysis: A Methode Surcebook: third edition. USA: Arizona State Univercity.

Sembiring, M. Gorky. 2009. Menjadi Guru Sejati. Yogyakarta: Galang Press.

Tim Penyusun Didaktik Kurikulum IKIP Surabaya, 2011. Pengantar Didaktik Metodik Kurikulum PBM. Surabaya: Rajawali Pers,

Tim Penyusun Didaktik Kurikulum IKIP Surabaya. 2011. Pengantar Didaktik Metodik Kurikulum PBM. Surabaya: Rajawali Pers.

Yusuf, A. Muri. 2017. Metode Penelitian Kuantitatif, Kualitatif \& Penelitian Gabungan. Jakarta: Kencana. 